\title{
Study on the mechanism of antibacterial action of magnesium oxide nanoparticles against foodborne pathogens
}

\author{
Yiping He ${ }^{1 *}$, Shakuntala Ingudam², Sue Reed ${ }^{1}$, Andrew Gehring ${ }^{1}$, Terence P. Strobaugh Jr. ${ }^{1}$ and Peter Irwin ${ }^{1}$
}

\begin{abstract}
Background: Magnesium oxide nanoparticles ( $\mathrm{MgO}$ nanoparticles, with average size of $20 \mathrm{~nm}$ ) have considerable potential as antimicrobial agents in food safety applications due to their structure, surface properties, and stability. The aim of this work was to investigate the antibacterial effects and mechanism of action of $\mathrm{MgO}$ nanoparticles against several important foodborne pathogens.
\end{abstract}

Results: Resazurin (a redox sensitive dye) microplate assay was used for measuring growth inhibition of bacteria treated with $\mathrm{MgO}$ nanoparticles. The minimal inhibitory concentrations of $\mathrm{MgO}$ nanoparticles to $10^{4}$ colony-forming unit/ml (CFU/ml) of Campylobacter jejuni, Escherichia coli O157:H7, and Salmonella Enteritidis were determined to be $0.5,1$ and $1 \mathrm{mg} / \mathrm{ml}$, respectively. To completely inactivate $10^{8-9} \mathrm{CFU} / \mathrm{ml}$ bacterial cells in $4 \mathrm{~h}$, a minimal concentration of $2 \mathrm{mg} / \mathrm{ml} \mathrm{MgO}$ nanoparticles was required for C. jejuni whereas E. coli O157:H7 and Salmonella Enteritidis required at least $8 \mathrm{mg} / \mathrm{ml}$ nanoparticles. Scanning electron microscopy examination revealed clear morphological changes and membrane structural damage in the cells treated with MgO nanoparticles. A quantitative real-time PCR combined with ethidium monoazide pretreatment confirmed cell membrane permeability was increased after exposure to the nanoparticles. In a cell free assay, a low level $(1.1 \mu \mathrm{M})$ of $\mathrm{H}_{2} \mathrm{O}_{2}$ was detected in the nanoparticle suspensions. Consistently, $\mathrm{MgO}$ nanoparticles greatly induced the gene expression of $\mathrm{KatA}$, a sole catalase in C. jejuni for breaking down $\mathrm{H}_{2} \mathrm{O}_{2}$ to $\mathrm{H}_{2} \mathrm{O}$ and $\mathrm{O}_{2}$.

Conclusions: $\mathrm{MgO}$ nanoparticles have strong antibacterial activity against three important foodborne pathogens. The interaction of nanoparticles with bacterial cells causes cell membrane leakage, induces oxidative stress, and ultimately leads to cell death.

Keywords: $\mathrm{MgO}$ nanoparticles, Foodborne pathogens, Antimicrobial mechanism, $\mathrm{H}_{2} \mathrm{O}_{2}$, Oxidative stress

\section{Background}

Campylobacter jejuni, Escherichia coli O157:H7, and Salmonella are the most common foodborne pathogens responsible for millions of cases of illnesses and hundreds of deaths each year in the United States [1]. C. jejuni is a spiral shaped and oxygen-sensitive microaerophile, whereas E. coli O157:H7 and Salmonella are rod shaped

\footnotetext{
${ }^{*}$ Correspondence: yiping.he@ars.usda.gov

${ }^{1}$ Molecular Characterization of Foodborne Pathogens Research Unit, Eastern Regional Research Center, Agricultural Research Service, United States Department of Agriculture, 600 East Mermaid Lane, Wyndmoor, PA 19038, USA

Full list of author information is available at the end of the article
}

and facultative anaerobic bacteria [2]. The main natural reservoirs for these bacteria are intestinal tracts of birds (e.g. chicken) and other animals (e.g. cattle) [3-5]. Transmission of these pathogens from animal feces or the environment to food can occur during harvesting, processing, distribution, and preparation of food. Pathogen contamination has been frequently found in various food products including meat, fresh produce, dairy products, and ready-to-eat foods. The sporadic prevalence of microbial pathogens in food and increased incidence of antibiotic resistant strains have posed serious concerns to public health $[6,7]$. Hence, there is a need to develop alternative strategies for effective control of microbial pathogens in food and the environment. 
Metal oxide nanoparticles such as $\mathrm{ZnO}, \mathrm{MgO}, \mathrm{CuO}$, $\mathrm{CaO}, \mathrm{Ag}_{2} \mathrm{O}$, and $\mathrm{TiO}_{2}$ are a new class of antimicrobial agents that have been increasingly studied for their antibacterial properties and potential applications in food, the environment, and healthcare [8, 9]. As nanoscale $(<100 \mathrm{~nm})$ inorganic materials, metal oxide nanoparticles have distinct features including broad spectrum antibacterial activity, large surface area of interaction with cells, low possibility for bacteria to develop resistance, high stability even under harsh conditions, and tunable sizes, shapes, surface properties, and chemical compositions, which lead to great potential for developing nanomaterials as effective antimicrobial agents. Among these, nanostructured $\mathrm{MgO}$ is particularly interesting due to its strong antibacterial activity, but high thermal stability and low cost.

The mechanism of metal oxide nanoparticle action on bacteria is complicated and not fully understood. It has been reported that the antibacterial activity of $\mathrm{MgO}$ nanoparticles is attributed to the production of reactive oxygen species (ROS) which induce lipid peroxidation in bacteria [10]. In contrast, non-ROS mediated bacterial toxicity was also found in $\mathrm{MgO}$ nanoparticles, suggesting oxidative stress might not be the primary mechanism of cell death [11]. Furthermore, the antibacterial effect not only depends upon the sizes, shapes, chemical composition, and surface properties (e.g. hydrophobicity) of the nanoparticles, but also varies with bacterial species [12, 13]. Several studies have shown that smaller particles have greater antibacterial activity due to higher reactive surface area [9]. However, aggregations of very small nanoparticles $(\sim 5 \mathrm{~nm})$ could reduce the efficiency of interaction with bacteria. It also has been reported that $\mathrm{MgO}$ and $\mathrm{CuO}$ nanoparticles had substantially higher antibacterial activities on Gram-positive (G+) than Gram-negative $(\mathrm{G}-$ ) bacteria, presumably due to the differences in cell membrane structure between these organisms. Our previous study showed that $\mathrm{ZnO}$ nanoparticles displayed extremely strong activity against $C$. jejuni compared to $E$. coli O157:H7 or Salmonella likely due to the different tolerances of these organisms to oxidative stress induced by nanoparticles [13].

Cytotoxicity is a major concern in the development of antimicrobial agents. $\mathrm{MgO}$ has been used as a mineral supplement for magnesium, an essential nutrient for the human body. As a medicine, $\mathrm{MgO}$ is used for the relief of cardiovascular disease and stomach problems. At low concentrations $(0.3 \mathrm{mg} / \mathrm{ml}), \mathrm{MgO}$ nanoparticles were reported to not be toxic to human cells [14]. However, toxic effects are greatly dependent on the physical and chemical properties of nanoparticles as well as the types of cells tested $[15,16]$. Hence, extensive evaluation of nanoparticles on different biological systems is needed to determine the toxicity of nanoparticles. Understanding of the mechanism of nanoparticle action on bacteria could provide useful guidelines for rational design and assembly of effective antibacterial derivatives. Advanced strategies, such as packaging multiple antimicrobial agents into the same nanoparticle, coating nanoparticles with biodegradable materials, and engineering target-specific nanoparticles for delivery to infection site, have emerged to improve antimicrobial activities and reduce undesirable side effects of nanoparticles.

The aim of this research was to study the antimicrobial activity and mechanism of action of $\mathrm{MgO}$ nanoparticles on three major foodborne pathogens. Through scanning electron microscopy (SEM) examination of cell morphology and membrane structure, ethidium monoazide combined with quantitative real-time PCR (EMA-qPCR) measurement of membrane permeability, transcriptional analysis of oxidative stress defense genes, and quantification of $\mathrm{H}_{2} \mathrm{O}_{2}$ produced in nanoparticle suspensions, we suggested the most conceivable mechanism of action of $\mathrm{MgO}$ nanoparticles on bacteria.

\section{Methods MgO nanoparticles}

$\mathrm{MgO}$ nanoparticles with an average size of $20 \mathrm{~nm}$ were purchased from Nanostructured \& Amorphous Materials, Inc. (Houston, $\mathrm{TX}, \mathrm{USA})$. $\mathrm{ZnO}$ nanoparticles (average size of $30 \mathrm{~nm}$ ) were from Inframat Advanced Materials LLC (Manchester, CT, USA). A stock suspension $(8 \mathrm{mg} / \mathrm{ml})$ was freshly prepared by resuspending

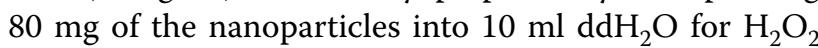
production assay or Mueller Hinton broth ( $\mathrm{MH}$ broth; Becton-Dickinson Co., Sparks, MD, USA) for cell culture experiments. All of the nanoparticle suspensions were homogenized by vigorous vortexing prior to use in the following experiments.

\section{Bacterial culture conditions}

Campylobacter jejuni 81-176 was statically grown at $42{ }^{\circ} \mathrm{C}$ in $\mathrm{MH}$ broth in a microaerophilic workstation (Don Whitley Scientific, Ltd., Shipley, UK) maintaining an atmosphere of $5 \% \mathrm{O}_{2}, 10 \% \mathrm{CO}_{2}, 85 \% \mathrm{~N}_{2}$, and $82 \%$ relative humidity. Salmonella enterica serovar Enteritidis ATCC 13076 and E. coli O157:H7 EDL 933 were aerobically grown at $37{ }^{\circ} \mathrm{C}$ in $\mathrm{MH}$ broth with shaking at 190 revolution per minute (rpm) (Innova 42, New Brunswick, Enfield, CT, USA).

\section{Minimum inhibitory concentration of $\mathrm{MgO}$ nanoparticles}

The viability of bacterial cells when exposed to varying concentrations of $\mathrm{MgO}$ nanoparticles was analyzed in a 96-well plate using the Resazurin Cell Viability Assay Kit (Bio Trend Chemicals LLC, Destin, FL, USA). 
Resazurin indicates cell viability by changing from a blue/ non-fluorescent state to a pink/highly fluorescent state upon chemical reduction resulting from aerobic respiration due to cell growth. Overnight cultures of $C$. jejuni, E. coli $\mathrm{O} 157: \mathrm{H7}$, and $S$. Enteritidis were diluted to approx. $10^{4} \mathrm{CFU} / \mathrm{ml}$. MgO nanoparticles were diluted 1:2 in $\mathrm{MH}$ broth from a starting concentration of $8 \mathrm{mg} / \mathrm{ml}$ in successive columns of a microtiter plate to an ending concentration of $0.03 \mathrm{mg} / \mathrm{ml}$. To each well containing $100 \mu \mathrm{l}$ of $\mathrm{MgO}$ nanoparticle suspension and $100 \mu \mathrm{l}$ of the diluted bacteria, $20 \mu \mathrm{l}$ of Resazurin dye was added and mixed thoroughly. Each microorganism was tested in a different plate with eight replicates of each concentration of $\mathrm{MgO}$ nanoparticles. Three controls without nanoparticles $(100 \mu \mathrm{l}$ each of MH broth without cells, and live and heat-killed cells at $10^{4} \mathrm{CFU} / \mathrm{ml}$ ) were also included in each plate. The plates were then incubated aerobically at $37{ }^{\circ} \mathrm{C}$ for E. coli and Salmonella or under microaerophilic conditions overnight at $42{ }^{\circ} \mathrm{C}$ for Campylobacter. After incubation, the plates were subjected to fluorescence measurement at an excitation wavelength of $530 \mathrm{~nm}$ and emission wavelength of $590 \mathrm{~nm}$ using a Tecan Safire $2^{\mathrm{TM}}$ microplate reader (Männedorf, Switzerland) as well as visual inspection for color change. The lowest concentration of nanoparticle suspension that inhibited cell growth (dye did not convert to red) was defined as the minimum inhibitory concentration (MIC).

\section{Antimicrobial effects of $\mathrm{MgO}$ nanoparticles}

The antimicrobial effects of $\mathrm{MgO}$ nanoparticles were studied by exposing $10^{8-9} \mathrm{CFU} / \mathrm{ml}$ of C. jejuni, E. coli O157:H7, and $S$. Enteritidis to 0, 0.5, 1, 2, 4 and $8 \mathrm{mg} / \mathrm{ml}$ nanoparticles. The samples were incubated aerobically at $37{ }^{\circ} \mathrm{C}$ for E. coli and Salmonella or microaerobically at $42{ }^{\circ} \mathrm{C}$ for Campylobacter for a total of $24 \mathrm{~h}$. At specific time intervals $(0,0.5,1,2,4,6$ and $8 \mathrm{~h}), 1 \mathrm{ml}$ of each sample was collected to determine colony-forming units (CFU) on $\mathrm{MH}$ agar by the $6 \times 6$ drop plate method [17]. The average number of CFU/ml $\left(\log _{10}\right)$ and standard deviation from 6 replicates were used to plot each data point.

\section{Morphological analysis by scanning electron microscope}

Bacterial cultures of E. coli O157:H7, S. Enteritidis, and C. jejuni were treated with 0,1 and $2 \mathrm{mg} / \mathrm{ml} \mathrm{MgO}$ nanoparticles for $8 \mathrm{~h}$. Aliquots of $1 \mathrm{ml}$ samples were centrifuged for $2 \mathrm{~min}$ at $4000 \mathrm{rpm}$ and the cell pellets were resuspended in $0.1 \mathrm{ml} \mathrm{MH}$ broth. Subsequently, $20 \mu \mathrm{l}$ of each concentrated sample was deposited and spread onto a glass coverslip pre-washed with acetone and ethanol. After drying the slips for $15 \mathrm{~min}$ at $37{ }^{\circ} \mathrm{C}$, the bacterial cells were subjected to fixation, dehydration, and critical point drying for SEM analysis as described previously [13].

\section{EMA-qPCR assessment of cell membrane integrity}

EMA-qPCR analysis of C. jejuni, E. coli O157:H7, and $S$. Enteritidis cells treated and untreated with $\mathrm{MgO}$ nanoparticles was carried out as described previously [18]. Briefly, late log phase cultures of Campylobacter were treated with 0,1 and $2 \mathrm{mg} / \mathrm{ml}$ of $\mathrm{MgO}$ nanoparticles for $8 \mathrm{~h}$ at $42{ }^{\circ} \mathrm{C}$ in microaerophilic conditions. E. coli and Salmonella were treated with 0,2 and $4 \mathrm{mg} / \mathrm{ml}$ of nanoparticles for $8 \mathrm{~h}$ aerobically at $37^{\circ} \mathrm{C}$. After incubation, $1 \mathrm{ml}$ of each sample was treated with $20 \mu \mathrm{g} / \mathrm{ml}$ EMA in the dark for $5 \mathrm{~min}$ and subsequently exposed to a $600 \mathrm{~W}$ halogen light for $1 \mathrm{~min}$ on ice. Cells were immediately centrifuged at $8000 \mathrm{rpm}$ for $5 \mathrm{~min}$ and washed with phosphate-buffered saline. Genomic DNA was extracted from the samples using the DNeasy Blood and Tissue kit (Qiagen, Valencia, CA, USA) and qPCR analyzed using a 7500 Real-Time PCR system (Applied Biosystems, Carlsbad, CA, USA). In the qPCR assay, organism-specific gene targets (hip $O, r f b E$, and $i n v A$ ), primers and TaqMan probes, and DNA standard curves were chosen for the detection of C. jejuni, E. coli, and Salmonella, respectively [18, 19]. The threshold cycle $(\mathrm{Ct})$ values obtained from the EMAqPCR assay were converted to DNA copy numbers based on the linear regression equations of the DNA standard curves. The copy number of the DNA target is equivalent to the genome copy of the bacterial cells and provides a good estimate for the number of cells.

\section{Gene expression analysis of nanoparticle treated and untreated cells}

Total cellular RNA was extracted from $100 \mathrm{ml}$ of late$\log$ phase (13 h microaerobic incubation) C. jejuni culture treated with 0 and $1 \mathrm{mg} / \mathrm{ml} \mathrm{MgO}$ nanoparticles for 30 min by using TRI-Reagent ${ }^{\circledR}$ (Molecular Research Center, Inc. Cincinnati, OH, USA). DNase I treatment and reverse transcription of the RNA samples were carried out as previously described [20]. The expression of stress response genes was quantified by a real-time PCR assay using SYBR green master mix (Applied Biosystems, Foster City, CA, USA) and the primer sets described in our previous report [13]. Housekeeping genes tsf, gyrA, and $16 S$ rRNA were included as references for data normalization. The difference of gene expression between nanoparticle treated and untreated cells was calculated using $2^{-\Delta \Delta \mathrm{Ct}}$ formula: $\Delta \Delta \mathrm{Ct}=\Delta \mathrm{Ct}$ (treated sample) $-\Delta \mathrm{Ct}$ (untreated sample), $\Delta \mathrm{Ct}=\mathrm{Ct}$ (target gene) $-\mathrm{Ct}$ (16S rRNA), and Ct is the threshold cycle value of the amplified target or reference gene [21].

\section{Quantification of $\mathrm{H}_{2} \mathrm{O}_{2}$ production in $\mathrm{MgO}$ and $\mathrm{ZnO}$ nanoparticle suspensions}

The assay of $\mathrm{H}_{2} \mathrm{O}_{2}$ released from nanoparticle suspensions was performed in a 96-well plate using the Red 
Hydrogen Peroxide Assay Kit (Enzo Life Sciences, Inc. Farmingdale, NY, USA). The assay utilizes horseradish peroxidase (HRP) to catalyze the conversion of a red peroxidase substrate into resorufin (a highly colored and fluorescent compound) during the reduction of $\mathrm{H}_{2} \mathrm{O}_{2}$ to $\mathrm{O}_{2}$ and $\mathrm{H}_{2} \mathrm{O}$. Scanning of resorufin absorbance was used for the detection of $\mathrm{H}_{2} \mathrm{O}_{2}$ production. Briefly, a $5 \mathrm{ml}$ reagent mix was prepared by adding $50 \mu \mathrm{l}$ of red peroxidase substrate $(100 \times)$ and $200 \mu \mathrm{l}$ of HRP (20 units/ml) into $4.75 \mathrm{ml}$ assay buffer. To each well of a microtiter plate, $100 \mu \mathrm{l}$ each of the freshly prepared reagent mixture and nanoparticle suspensions $(0.5,1,2$ and $4 \mathrm{mg} / \mathrm{ml})$ were added. After 1-h incubation at room temperature, the plate was centrifuged at $4000 \mathrm{rpm}$ for $5 \mathrm{~min}$ to pellet the nanoparticles. Subsequently, $100 \mu \mathrm{l}$ supernatant from each well was transferred into an ultraviolet (UV) transparent plate and scanned for absorbance between 475 and $600 \mathrm{~nm}$ wavelengths using a Tecan Safire $2^{\mathrm{TM}}$ microplate reader. To estimate the $\mathrm{H}_{2} \mathrm{O}_{2}$ concentrations in the nanoparticle suspensions, a standard curve was prepared using a set of $1: 3$ serial dilutions of $\mathrm{H}_{2} \mathrm{O}_{2}$ in distilled water $(10,3.33,1.11,0.37,0.12,0.04$ and $0.01 \mu \mathrm{M})$ and scanned in the same assay. Distilled water was used as a blank for scanning. Each of the samples including the standards were analyzed in duplicate.

\section{Results}

\section{Minimum inhibitory concentration of MgO nanoparticles}

The viability of C. jejuni, E. coli O157:H7, and S. Enteritidis when exposed to varying concentrations of $\mathrm{MgO}$ nanoparticles was determined using an oxidation-reduction assay. Resazurin, a redox sensitive dye, was used to indicate cell viability. Metabolically active cells reduce the non-fluorescent blue resazurin to fluorescent red resorufin. Non-living cells do not reduce the resazurin, and thus indicate cell death. This visible change in color and fluorescence indicates the cells are viable. Freshly grown and diluted bacterial cultures in $\mathrm{MH}$ broth (approx. $10^{4} \mathrm{CFU} /$ $\mathrm{ml}$ ) were exposed to $\mathrm{MgO}$ nanoparticles at concentrations ranging from 0.03 to $8 \mathrm{mg} / \mathrm{ml}$. C. jejuni cells were rendered non-viable after treatment with $0.5 \mathrm{mg} / \mathrm{ml}$ of MgO nanoparticles. E. coli O157:H7 and S. Enteritidis were inactivated with $1 \mathrm{mg} / \mathrm{ml}$ of $\mathrm{MgO}$ nanoparticles (Fig. 1). This indicates that C. jejuni is more susceptible to the antimicrobial effects of $\mathrm{MgO}$ nanoparticles than $E$. coli $\mathrm{O} 157: \mathrm{H} 7$ or $S$. Enteritidis.

\section{Lethal effect of $\mathrm{MgO}$ nanoparticles}

The observed antimicrobial effect was further investigated by exposing $10^{8} \mathrm{CFU} / \mathrm{ml} C$. jejuni and $10^{9} \mathrm{CFU} / \mathrm{ml}$ E. coli O157:H7 and S. Enteritidis to 0, 0.5, 1, 2, 4 and $8 \mathrm{mg} / \mathrm{ml} \mathrm{MgO}$ nanoparticles over a set time trial (Fig. 2). Live cells were measured by the colony forming units on

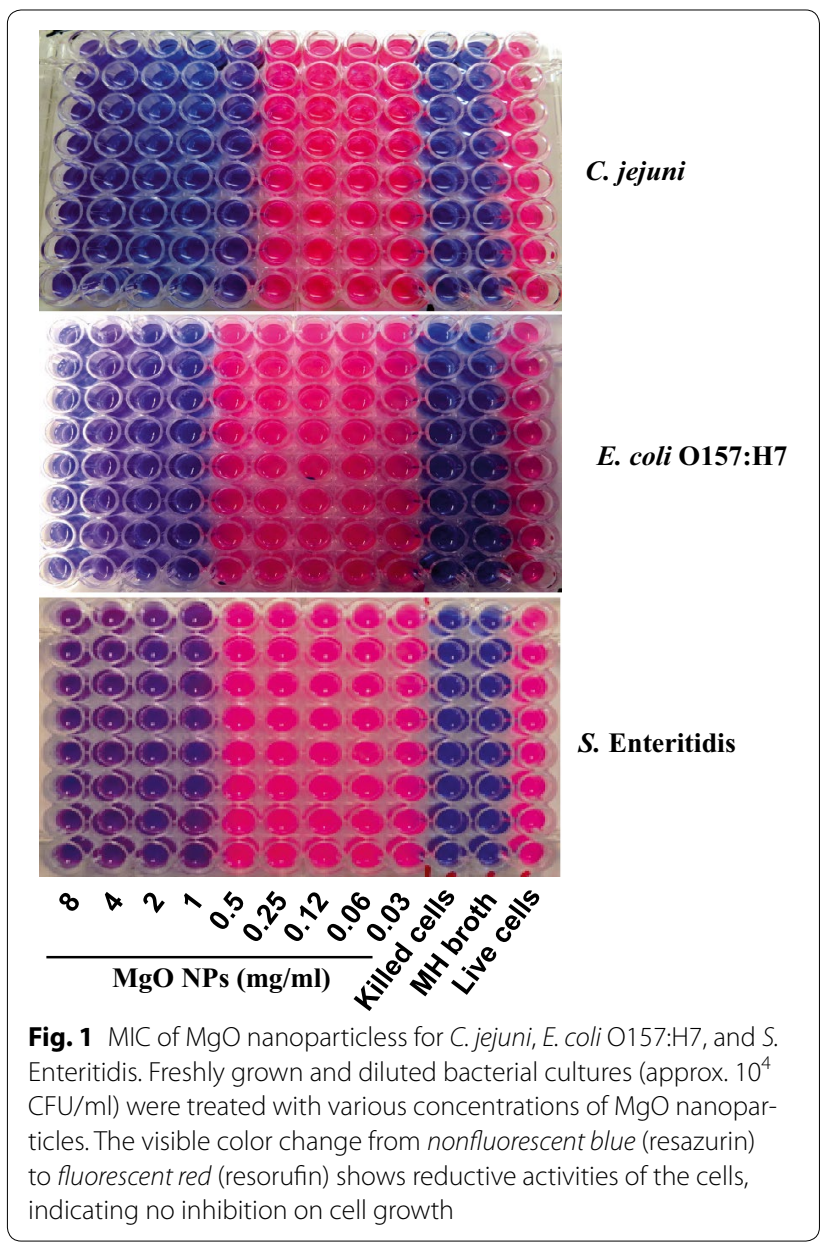

$\mathrm{MH}$ agar. At a concentration of $2 \mathrm{mg} / \mathrm{ml} \mathrm{MgO}$ nanoparticles, C. jejuni was reduced 6 orders of magnitude after $2 \mathrm{~h}$ and completely killed after $4 \mathrm{~h}$. At $4 \mathrm{mg} / \mathrm{ml}, C$. jejuni was completely killed within $1 \mathrm{~h}$. On the contrary, $8 \mathrm{mg} /$ $\mathrm{ml} \mathrm{MgO}$ nanoparticles were required to kill all $E$. coli O157:H7 and S. Enteritidis cells in $4 \mathrm{~h}$ and $4 \mathrm{mg} / \mathrm{ml}$ in 6 h. In addition, E. coli O157:H7 could also be killed by $2 \mathrm{mg} / \mathrm{ml}$ in $8 \mathrm{~h}$, whereas $S$. Enteritidis was only reduced 5 logs after the same exposure. This demonstrates again that $\mathrm{MgO}$ nanoparticles are effective at killing C. jejuni at low concentrations in short periods of time. They are also advantageous at killing E. coli O157:H7 and S. Enteritidis within $4 \mathrm{~h}$.

\section{MgO nanoparticles alter bacterial cell morphology and membrane structure}

To explore antimicrobial mechanism of the nanoparticles, scanning electron microscopy was used to examine the morphological and membrane structure changes of C. jejuni, E. coli O157:H7, and S. Enteritidis induced by $\mathrm{MgO}$ nanoparticles. Bacterial cells in late-log growth 


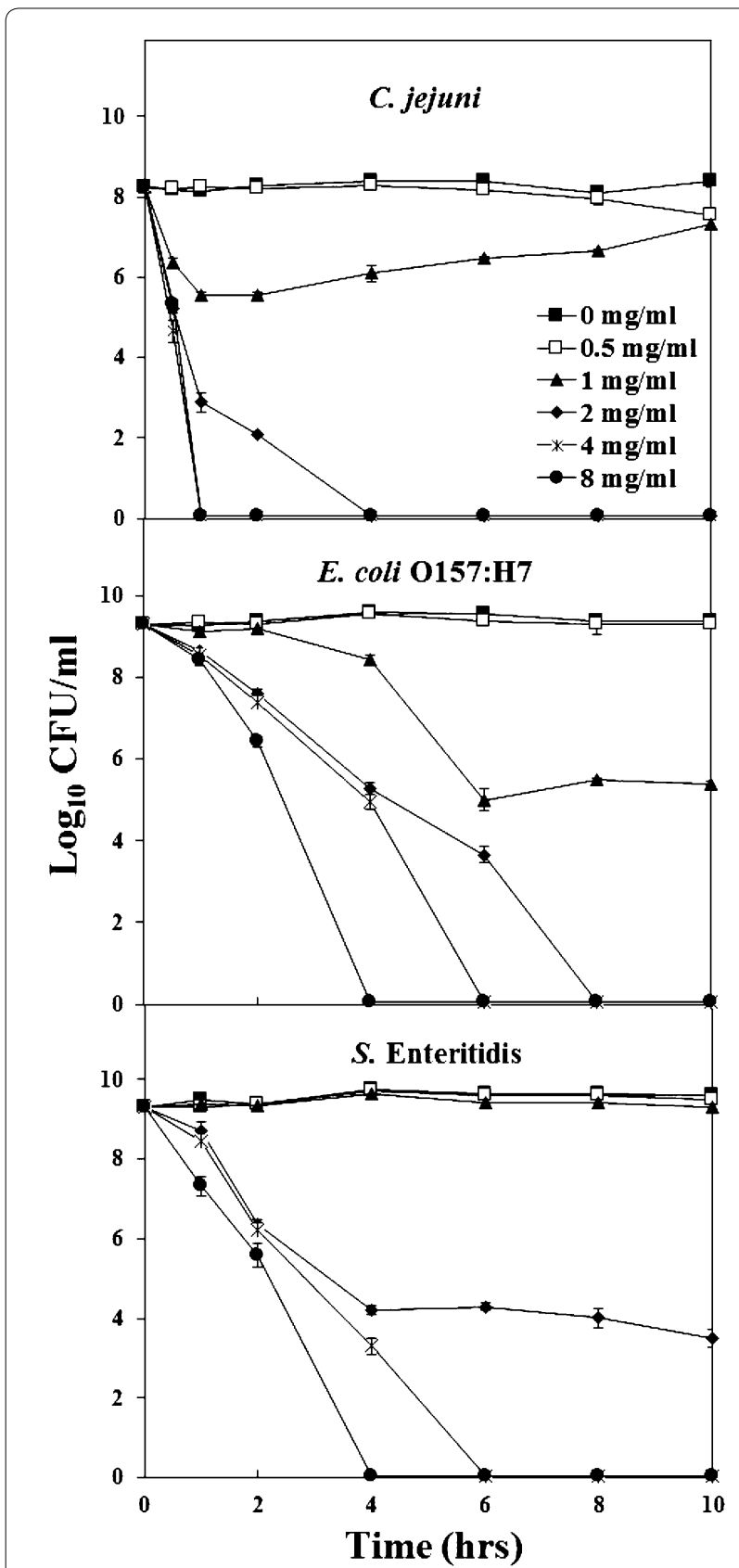

Fig. 2 Antimicrobial effect of $\mathrm{MgO}$ nanoparticles against C. jejuni, $E$. coli O157:H7, and S. Enteritidis. Various concentrations of nanoparticles were applied to approx. $10^{8} \mathrm{CFU} / \mathrm{ml}$ of C. jejuni and $10^{9} \mathrm{CFU} / \mathrm{ml}$ of E. coli O157:H7 or S. Enteritidis. At different times after the treatment, viable cell counts were measured by culturing bacterial colonies on $\mathrm{MH}$ agar plates. Each of the $\mathrm{CFU} / \mathrm{ml}$ value represents the mean of six replicates

were treated with sub-lethal doses of $\mathrm{MgO}$ nanoparticles ( 1 and $2 \mathrm{mg} / \mathrm{ml}$ ) for $4 \mathrm{~h}$ and collected for SEM study. Both treated and untreated cells were incubated under the same conditions and analyzed by SEM in parallel in order to observe the differences between the control and cells exposed to nanoparticles. SEM images in Fig. 3 show all of the untreated cells have intact and smooth surfaces. As expected, C. jejuni cells are spiral-shaped, whereas $E$. coli O157:H7 and S. Enteritidis are rod-shaped. After incubation with a sub-lethal concentration of nanoparticles, $C$. jejuni cells underwent significant morphological changes from spiral to coccoid form, but E. coli O157:H7 and S. Enteritidis remained rod shaped. Noticeably, all of the treated cells displayed some deep craters on their membrane surface, indicating a degree of membrane structure damage. These cells appear to be shorter and more compact, suggesting there could be some leakage of the cellular contents caused by the treatment. No cell lysis was noticed after the treatment of sub-lethal concentrations of nanoparticles.

\section{$\mathrm{MgO}$ nanoparticles increase $C$. jejuni membrane permeability}

To further investigate the effect of $\mathrm{MgO}$ nanoparticles on cell membrane integrity and permeability, ethidium monoazide-qPCR assay was employed. Ethidium monoazide (EMA) is a DNA-binding intercalator that enters cells through compromised membranes. After photo crosslinking, the intercalation between EMA and cellular DNA becomes irreversible due to the formation of intermolecular covalent bonds. The EMA-bound DNA cannot be amplified by PCR, thus indicating membrane damage.

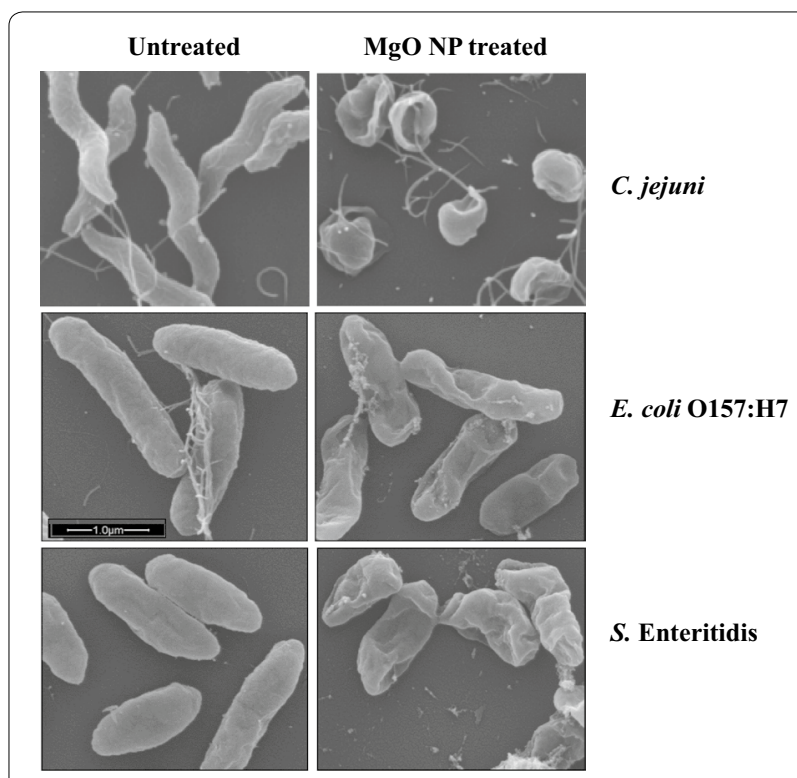

Fig. 3 Scanning electron micrographs of C. jejuni, E. coli O157:H7, and S. Enteritidis. SEM images were taken from the bacterial cells of C. jejuni, E. coli O157:H7, and S. Enteritidis treated (right panel) with $2 \mathrm{mg} / \mathrm{ml} \mathrm{MgO}$ nanoparticles for $8 \mathrm{~h}$. The control cells (left panel) were incubated under the same conditions without adding nanoparticles 
The membrane permeability of $C$. jejuni after exposure to 1 and $2 \mathrm{mg} / \mathrm{ml} \mathrm{MgO}$ nanoparticles for $4 \mathrm{~h}$ was assessed by EMA-qPCR assay. The results in Fig. 4 show that cells exposed to $\mathrm{MgO}$ nanoparticles had a nearly 1-log reduction in DNA amplification, indicating EMA penetration via damaged membranes. Similar experiments were performed on E. coli O157:H7 and S. Enteritidis cells after exposure to 2 and $4 \mathrm{mg} / \mathrm{ml} \mathrm{MgO}$ nanoparticles. The effects of membrane leakage by $\mathrm{MgO}$ nanoparticles were less noticeable compared to C. jejuni (data not shown). Together, these results indicate that $\mathrm{MgO}$ nanoparticles increase cell membrane permeability and that $C$. jejuni is more susceptible to the membrane damage than E. coli O157:H7 and S. Enteritidis.

\section{$\mathrm{MgO}$ nanoparticles induce the expression of oxidative stress response genes in C. jejuni}

To study the molecular mechanism of $\mathrm{MgO}$ nanoparticle action on bacteria, expression of the genes involved in oxidative and general stress defenses was examined in C. jejuni. Late-log phase cells exposed to $1 \mathrm{mg} / \mathrm{ml} \mathrm{MgO}$ nanoparticles for $30 \mathrm{~min}$ were collected for transcription analysis. Transcripts/mRNAs of these genes were prepared and quantified by reverse transcription-qPCR. In response to the treatment, the expression of oxidative stress response genes katA (encoding catalase), $a h p C$ (encoding alkyl hydroperoxide reductase), and $d p s$ (encoding bacterioferritin) were upregulated 44-, 5- and 4-fold, respectively (Fig. 5). In addition, general stress response gene spoT [encoding a bifunctional (p) ppGpp synthetase/hydrolase] was also expressed 22 -fold higher. As controls, transcriptions of housekeeping genes gyrA, $t s f$, and $16 \mathrm{~s}$ rRNA were not significantly affected. $k a t A$ is the sole catalase gene present in $C$. jejuni and is essential for resistance to hydrogen peroxide [22]. spoT is a stringent response gene required for survival under high $\mathrm{O}_{2}$

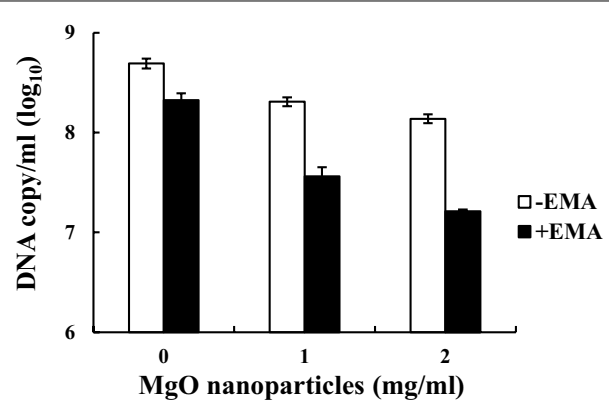

Fig. 4 EMA-qPCR analysis of $C$. jejuni membrane permeability. $C$. jejuni cells exposed to 0,1 or $2 \mathrm{mg} / \mathrm{ml}$ of nanoparticles were measured for the inhibition of DNA amplification caused by the penetrated EMA. The inhibition of DNA amplification was monitored by qPCR of the hipO gene. In the presence of EMA, reduced DNA amplification indicates increased membrane permeability in the cells
[23]. Dramatic increase of the catalase gene (katA) and stringent response gene (spoT) expression in response to treatment strongly suggests $\mathrm{MgO}$ nanoparticles induce oxidative stress in C. jejuni cells. To survive, bacteria regulate their detoxification system by increasing their level of oxidative stress defense proteins as well as some of the general stress response proteins.

\section{Nanoparticle suspensions generate hydrogen peroxide}

To further investigate the causes of oxidative stress in bacteria by $\mathrm{MgO}$ nanoparticles, we measured hydrogen peroxide $\left(\mathrm{H}_{2} \mathrm{O}_{2}\right)$ produced in nanoparticle suspensions by using the highly sensitive Red Hydrogen Peroxide assay kit (with sensitivity as low as $10 \mathrm{pmol}$ ). $\mathrm{H}_{2} \mathrm{O}_{2}$ contains a highly reactive oxygen species and is able to penetrate into cells to cause oxidative stress. Since $\mathrm{H}_{2} \mathrm{O}_{2}$ is the most unstable form of reactive oxygen species, all the nanoparticle suspensions and $\mathrm{H}_{2} \mathrm{O}_{2}$ standard solutions were freshly prepared for the study. The levels of $\mathrm{H}_{2} \mathrm{O}_{2}$ produced in nanoparticle suspensions were determined by scanning the absorbance of resorufin fluorescence between 475 and $600 \mathrm{~nm}$ wavelengths and shown in Fig. 6. Referenced to the fluorescent absorbance of known concentrations of $\mathrm{H}_{2} \mathrm{O}_{2}$ standards $(0.12,0.37,1.1$, 3.3 and $10 \mu \mathrm{M}$ ), the $\mathrm{H}_{2} \mathrm{O}_{2}$ released in $\mathrm{MgO}$ nanoparticle suspension was estimated to be ca. $1.1 \mu \mathrm{M}$. In the same assay, a low level of $\mathrm{H}_{2} \mathrm{O}_{2}$ (ca. $0.12 \mu \mathrm{M}$ ) was also detected in $\mathrm{ZnO}$ nanoparticle suspensions, suggesting the $\mathrm{H}_{2} \mathrm{O}_{2}$ generated from $\mathrm{MgO} / \mathrm{ZnO}$ nanoparticles contributed to antibacterial activity by inducing oxidative stress in cells.

\section{Discussion}

In this study, we have shown that MgO nanoparticles have a strong antimicrobial activity against three major foodborne pathogens from both the microplate-based resazurin assay and viable cell count method. The use of visible color change of resazurin from blue to red as an indicator of cell growth not only made the detection simple and fast, but allowed us to avoid the turbidity problem of insoluble nanoparticles interfering with cell optical density measurements. By using this assay, we determined that the minimal inhibitory concentrations of $\mathrm{MgO}$ nanoparticles against $10^{4} \mathrm{CFU} / \mathrm{ml}$ of C. jejuni and E. coli O157:H7/Salmonella were 0.5 and $1 \mathrm{mg} / \mathrm{ml}$, respectively. This is reasonably close to the result reported by Krishnamoorthy et al. [24] which showed the MIC of $\mathrm{MgO}$ nanoparticles (average size $25 \mu \mathrm{M}$ ) to $5 \times 10^{5} \mathrm{CFU} / \mathrm{ml}$ of $E$. coli was $0.5 \mathrm{mg} / \mathrm{ml}$. The slight variances of the MICs found in these studies might be due to the size and/or shape variations of the nanoparticles or the different numbers of cells used.

By viable cell count, we found at least $2 \mathrm{mg} / \mathrm{ml}$ nanoparticles (equivalent to $1.3 \times 10^{14}$ of $20 \mathrm{~nm}$ size and sphere-shaped $\mathrm{MgO}$ nanoparticles per $\mathrm{ml}$ ) were required 


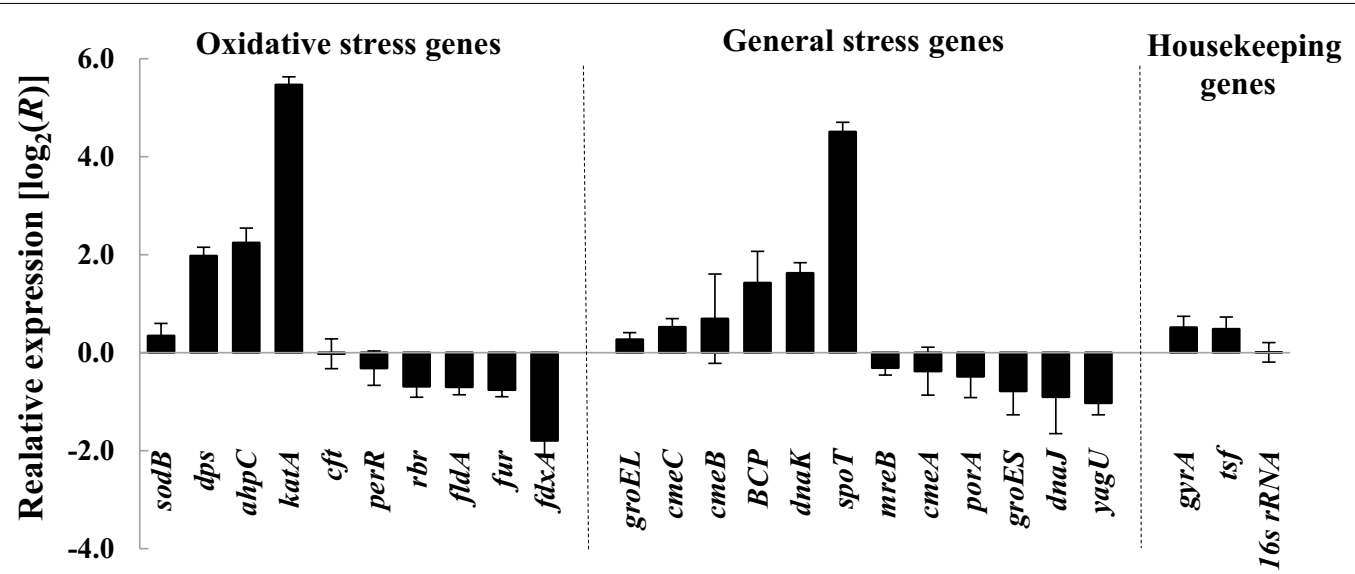

Fig. 5 Difference of stress gene expression between MgO nanoparticle treated and untreated C. jejuni. Late-log phase cells treated with 0 or 1 mg/ $\mathrm{ml} \mathrm{MgO}$ nanoparticles for 30 min were quantified for mRNA of stress genes by reverse transcription-qPCR. Relative expression ratio ( $\triangle \Delta \mathrm{Ct})$ of each gene is presented in a $\log _{2}$ value

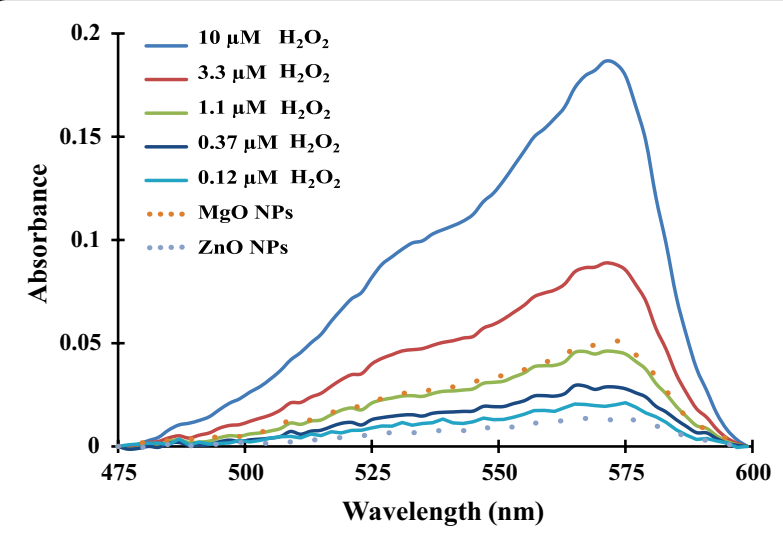

Fig. 6 Production of $\mathrm{H}_{2} \mathrm{O}_{2}$ in $\mathrm{MgO} / \mathrm{ZnO}$ nanoparticle suspensions. The production of $\mathrm{H}_{2} \mathrm{O}_{2}$ in nanoparticle suspensions was measured by spectral absorbance scanning of resorufin, a fluorescent compound formed from a peroxidase substrate by $\mathrm{H}_{2} \mathrm{O}_{2}$ reduction. The solid curves represent the absorbance of various known concentrations of $\mathrm{H}_{2} \mathrm{O}_{2}$ standards, and the dotted curves show the levels of $\mathrm{H}_{2} \mathrm{O}_{2}$ released from $\mathrm{MgO} / \mathrm{ZnO}$ nanoparticle suspensions after baseline subtraction. The maximum excitation and emission wavelengths of resorufin fluorescence are at 570 and $585 \mathrm{~nm}$, respectively

to completely inactivate $10^{8} \mathrm{CFU} / \mathrm{ml}$ of $C$. jejuni, and $4 \mathrm{mg} / \mathrm{ml}$ was the minimal amount of nanoparticles needed to kill $10^{9} \mathrm{CFU} / \mathrm{ml}$ of E. coli $\mathrm{O} 157: \mathrm{H} 7$ or Salmonella. Apparently, higher concentrations of $\mathrm{MgO}$ nanoparticles were required to inactivate increased numbers of bacterial cells. Also, C. jejuni cells were found to be more susceptible to the nanoparticles than E. coli O157:H7 or Salmonella.

In this study, we chose $C$. jejuni, a microaerophilic bacterium, as a model organism to study the expression of stress defense genes. C. jejuni is extremely sensitive to oxidative stress due to the lack of SoxRS and OxyR, the most important regulatory proteins of oxidative stress defense in E. coli and Salmonella. It has been known that $C$. jejuni uses a number of enzymes including KatA, SodB, AhpC, Dps, Tpx, and Bcp to detoxify a low level of endogenous $\mathrm{H}_{2} \mathrm{O}_{2}$ produced during cell metabolism and as a defense to the oxidative stresses potentially encountered in a host and the environment [25]. To better understand bacterial cell responses to the nanoparticle treatment, we selected a number of genes associated with oxidative stress and general stress defenses as targets of transcriptional study. Of the important anti-oxidative stress proteins in C. jejuni, KatA is the only catalase and primary enzyme for decomposing $\mathrm{H}_{2} \mathrm{O}_{2}$ to $\mathrm{H}_{2} \mathrm{O}$ and $\mathrm{O}_{2}$; AhpC is the secondary enzyme for reducing $\mathrm{H}_{2} \mathrm{O}_{2}$ and is responsible for removal of low level of $\mathrm{H}_{2} \mathrm{O}_{2}$ from cells; and Dps protects cellular DNA from oxidative damage [26-28].

From transcriptional analysis of the stress response genes, we found the expression of $k a t A, a h p C$, and $d p s$ were significantly increased in response to a sub-lethal concentration of $\mathrm{MgO}$ nanoparticle treatment. Interestingly, the same set of stress response genes (katA, ahpC, and $d p s$ ) were also found expressed at higher levels in the C. jejuni cells treated with $1 \mathrm{mM} \mathrm{H}_{2} \mathrm{O}_{2}$ [29]. $\mathrm{H}_{2} \mathrm{O}_{2}$ is highly reactive to cell biomolecules (e.g. DNA, proteins, and lipids) and causes oxidative stress in bacteria when present at high concentrations. Severe or continuous oxidative stress could result in failure of the cellular defense system and cell death. By using a highly sensitive cell-free assay, we detected approximately 0.12 and $1.1 \mu \mathrm{M} \mathrm{H}_{2} \mathrm{O}_{2}$ in $\mathrm{ZnO}$ and $\mathrm{MgO}$ nanoparticle suspensions, respectively. The concentrations of $\mathrm{H}_{2} \mathrm{O}_{2}$ produced in these nanoparticle suspensions seems to be relatively low, so it is possible 
that the production of $\mathrm{H}_{2} \mathrm{O}_{2}$ from nanoparticles is not the sole mechanism for the antibacterial activity of $\mathrm{MgO} /$ $\mathrm{ZnO}$ nanoparticles. SEM analysis showed considerable cell morphology change and membrane disruption in the cells treated with $\mathrm{MgO}$ nanoparticles. Furthermore, the EMA-qPCR results provided from this study confirmed that $\mathrm{MgO}$ nanoparticles increased membrane permeability in the bacteria which likely resulted in the leakage of cell content.

Our previous study showed $\mathrm{ZnO}$ nanoparticles had remarkable anti-Campylobacter activity with the MIC 8-16 fold lower than E. coli and Salmonella [13] In this study, we did not find significant differences of $\mathrm{MgO}$ nanoparticles in inhibiting growth or inactivating cells between C. jejuni, E. coli O157:H7, and S. Enteritidis. However, the effects of $\mathrm{ZnO}$ and $\mathrm{MgO}$ nanoparticles on triggering cell morphology change, membrane leakage, and oxidative stress, were found to be similar, suggesting the modes of actions of these nanoparticles on bacteria might be similar but not exactly the same.

On the basis of these findings, we propose multiple mechanisms for the action of $\mathrm{MgO}$ nanoparticles on bacteria: (1) $\mathrm{MgO}$ nanoparticles continuously generate a certain level of $\mathrm{H}_{2} \mathrm{O}_{2}$ while in suspension, which induces oxidative stress in cells; (2) physical interaction between nanoparticles and cell surface disrupts bacterial membrane integrity and causes membrane leakage; (3) higher concentrations of nanoparticles lead to severe membrane damage, cell content release, irreversible oxidization of biomolecules (e.g. DNA. proteins, and lipids), and ultimately cell death.

\section{Conclusions}

This study demonstrated that $\mathrm{MgO}$ nanoparticles have strong antibacterial activity against three important foodborne pathogens and addressed the underlying mechanisms of $\mathrm{MgO}$ nanoparticles' deleterious action on bacteria. The distinct evidence of $\mathrm{H}_{2} \mathrm{O}_{2}$ production in suspension of $\mathrm{MgO}$ nanoparticles, nanoparticleinduced expression of oxidative stress defense genes, alteration of cell morphology, and membrane leakage strongly suggests that the antibacterial mechanism of $\mathrm{MgO}$ nanoparticles is due to the induction of oxidative stress and disruption of membrane integrity in bacterial cells.

\footnotetext{
Abbreviations

CFU: colony forming unit; C. jejuni: Campylobacter jejuni; E. coli: Escherichia coli; S. Enteritidis: Salmonella Enteritidis; KatA: catalase; ROS: reactive oxygen species; G+: Gram positive; G-: Gram negative; SEM: scanning electron microscopy; EMA: ethidium monoazide; qPCR: quantitative real-time PCR; $\mathrm{MH}$ : Mueller-Hinton; MIC: minimum inhibitory concentration; rpm: revolution per minute; ATCC: American Type Culture Collection; Ct: threshold cycle; HRP: horseradish peroxidase; UV: ultraviolet.
}

\section{Authors' contributions}

YH designed all of the experiments, performed all calculations and statistical analyses, participated in running most of the experiments and prepared the manuscript. PI and SI performed the experiments and statistical data analyses. SR and TS performed the experiments and helped to draft the manuscript. AG assisted in certain aspects of the experiments as well as drafting the manuscript. All authors read and approved the final manuscript.

\section{Author details}

${ }^{1}$ Molecular Characterization of Foodborne Pathogens Research Unit, Eastern Regional Research Center, Agricultural Research Service, United States Department of Agriculture, 600 East Mermaid Lane, Wyndmoor, PA 19038, USA. ${ }^{2}$ ICAR Research Complex for NEH Region, Umiam 793103, Meghalaya, India.

\section{Acknowledgements}

This research was supported by the US Department of Agriculture, Agricultural Research Service (USDA-ARS), and the overseas associateship award from the Department of Biotechnology, the Government of India Ministry of Science and Technology.

United States Department of Agriculture is an equal opportunity provider and employer.

\section{Competing interests}

The authors declare that they have no competing interests.

Received: 31 March 2016 Accepted: 6 June 2016

Published online: 27 June 2016

\section{References}

1. Scallan E, Hoekstra RM, Angulo FJ, Tauxe RV, Widdowson M-A, Roy SL, et al. Foodborne illness acquired in the United States - major pathogens. Emerg Infect Dis. 2011;17:7-15.

2. Silva J, Leite D, Fernandes M, Mena C, Gibbs PA, Teixeira P. Campylobacter spp. as a foodborne pathogen: a review. Front Microbiol. 2011;2:200.

3. Young KT, Davis LM, Dirita VJ. Campylobacter jejuni: molecular biology and pathogenesis. Nat Rev Microbiol. 2007:5:665-79.

4. Ferens WA, Hovde CJ. Escherichia coli O157:H7: animal reservoir and sources of human infection. Foodborne Pathog Dis. 2011;8:465-87.

5. Kingsley RA, Baumler AJ. Host adaptation and the emergence of infectious disease: the Salmonella paradigm. Mol Microbiol. 2000;36:1006-14

6. O'Connell KM, Hodgkinson JT, Sore HF, Welch M, Salmond GP, Spring DR. Combating multidrug-resistant bacteria: current strategies for the discovery of novel antibacterials. Angew Chem Int Ed Engl. 2013;52:10706-33.

7. Neu HC. The crisis in antibiotic resistance. Science. 1992;257:1064-73.

8. Dizaj SM, Lotfipour F, Barzegar-Jalali M, Zarrintan MH, Adibkia K. Antimicrobial activity of the metals and metal oxide nanoparticles. Mater Sci Eng C Mater Biol Appl. 2014;44:278-84.

9. Hajipour MJ, Fromm KM, Ashkarran AA, Jimenez de Aberasturi D, de Larramendi IR, Rojo T, et al. Antibacterial properties of nanoparticles. Trends Biotechnol. 2012;30:499-511.

10. Tang ZX, Lv BF. MgO nanoparticles as antibacterial agent: preparation and activity. Braz J Chem Eng. 2014;31:591-601.

11. Leung YH, Ng AM, Xu X, Shen Z, Gethings LA, Wong MT, et al. Mechanisms of antibacterial activity of MgO: non-ROS mediated toxicity of $\mathrm{MgO}$ nanoparticles towards Escherichia coli. Small. 2014;10:1171-83.

12. Li X, Robinson SM, Gupta A, Saha K, Jiang Z, Moyano DF, et al. Functional gold nanoparticles as potent antimicrobial agents against multi-drugresistant bacteria. ACS Nano. 2014;8:10682-6.

13. Xie Y, He Y, Irwin PL, Jin T, Shi X. Antibacterial activity and mechanism of action of zinc oxide nanoparticles against Campylobacter jejuni. Appl Environ Microbiol. 2011;77:2325-31.

14. Ge S, Wang G, Shen Y, Zhang Q, Jia D, Wang H, et al. Cytotoxic effects of $\mathrm{MgO}$ nanoparticles on human umbilical vein endothelial cells in vitro. IET Nanobiotechnol. 2011;5:36.

15. Love SA, Maurer-Jones MA, Thompson JW, Lin YS, Haynes CL. Assessing nanoparticle toxicity. Annu Rev Anal Chem. 2012;5:181-205. 
16. Reddy KM, Feris K, Bell J, Wingett DG, Hanley C, Punnoose A. Selective toxicity of zinc oxide nanoparticles to prokaryotic and eukaryotic systems. Appl Phys Lett. 2007;90:2139021-3.

17. Chen C-Y, Nace GW, Irwin PL. A $6 \times 6$ drop plate method for simultaneous colony counting and MPN enumeration of Campylobacter jejuni, Listeria monocytogenes, and Escherichia coli. J Microbiol Methods. 2003:55:475-9.

18. He Y, Chen CY. Quantitative analysis of viable, stressed and dead cells of Campylobacter jejuni strain 81-176. Food Microbiol. 2010;27:439-46.

19. Suo B, He Y, Tu SI, Shi X. A multiplex real-time polymerase chain reaction for simultaneous detection of Salmonella spp., Escherichia coli O157, and Listeria monocytogenes in meat products. Foodborne Pathog Dis. 2010;7:619-28.

20. He Y, Frye JG, Strobaugh TP, Chen C-Y. Analysis of AI-2/LuxS-dependent transcription in Campylobacter jejuni strain 81-176. Foodborne Pathog Dis. 2008;5:399-415.

21. Livak KJ, Schmittgen TD. Analysis of relative gene expression data using real-time quantitative $P C R$ and the $2[-$ Delta Delta $C(T)]$ method. Methods. 2001;25:402-8.

22. Day WA Jr, Sajecki JL, Pitts TM, Joens LA. Role of catalase in Campylobacter jejuni intracellular survival. Infect Immun. 2000;68:6337-45.
23. Gaynor EC, Wells DH, MacKichan JK, Falkow S. The Campylobacter jejuni stringent response controls specific stress survival and virulence-associated phenotypes. Mol Microbiol. 2005;56:8-27.

24. Krishnamoorthy K, Manivannan G, Kim SJ, Jeyasubramanian K, Premanathan M. Antibacterial activity of $\mathrm{MgO}$ nanoparticles based on lipid peroxidation by oxygen vacancy. J Nanopart Res. 2012;14:1063.

25. Kim JC, Oh E, Kim J, Jeon B. Regulation of oxidative stress resistance in Campylobacter jejuni, a microaerophilic foodborne pathogen. Front Microbiol. 2015;6:751.

26. Baillon ML, van Vliet AH, Ketley JM, Constantinidou C, Penn CW. An iron-regulated alkyl hydroperoxide reductase (AhpC) confers aerotolerance and oxidative stress resistance to the microaerophilic pathogen Campylobacter jejuni. J Bacteriol. 1999;181:4798-804.

27. Huergo LF, Rahman H, Ibrahimovic A, Day CJ, Korolik V. Campylobacter jejuni Dps protein binds DNA in the presence of iron or hydrogen peroxide. J Bacteriol. 2013;195:1970-8.

28. Ishikawa T, Mizunoe Y, Kawabata S, Takade A, Harada M, Wai SN, et al. The iron-binding protein Dps confers hydrogen peroxide stress resistance to Campylobacter jejuni. J Bacteriol. 2003;185:1010-7.

29. Palyada K, Sun YQ, Flint A, Butcher J, Naikare H, Stintzi A. Characterization of the oxidative stress stimulon and PerR regulon of Campylobacter jejuni. BMC Genom. 2009;10:481.

\section{Submit your next manuscript to BioMed Central and we will help you at every step:}

- We accept pre-submission inquiries

- Our selector tool helps you to find the most relevant journal

- We provide round the clock customer support

- Convenient online submission

- Thorough peer review

- Inclusion in PubMed and all major indexing services

- Maximum visibility for your research

Submit your manuscript at www.biomedcentral.com/submit 